\title{
Perceiving and Exploring Multi-dimensional Roles of "Qanats" in Urban Sustainable Environments of Iran (The Case of Kashan-Yazd and Tehran)
}

\author{
Sina Razzaghi-Asl
}

\begin{abstract}
Qanat / Karez is one the most important and profound inventions of the Iran's Hydraulic engineering. Use of this technique to utilize the underground water (and sometimes groundwater) resources can be aged to more than 3000 years. Today, qanats are being used in 35 other countries, except Iran, in four different continents, and they are still used as irrigation mean.

As most publications have focused the technical side of the qanats, this article is trying to study the role of the qanats in the everyday life of the residents in cities like Kashan, Tehran and Yazd with emphasis on urban landscapes. And as such, with the structure interview and case study techniques, we will explore the realities and perceptions of people regarding the functional roles and aspects of qanats in different levels of each city.

This article's results will show that roles of qanats in the different aspects lives of the Iran's central cities residents which can be categorized into: Functional, Socio-cultural, Ecological, Economical, and Visual, Cooling, Psychological and tourism heritage. Therefore, different features relating to each of these roles are also provided.
\end{abstract}

Index Terms-Qanat, sustainable water resources, environment, infrastructure, urban form.

\section{INTRODUCTION}

There has been a stress on the importance of qanats as the first stable and regenerative system of irrigation in urban areas across the world [1], [2]. Approximately 4000 B.C., Iranian people with knowledge of geology and hydrology have had constructed qanat. It appears that the people of the kingdom of Urartu (the city of Uhli, present-dat Marand), just north of the Zagros, solved the problem with a system of undergrounded conduits to channel snowmelt. Sargon II of Assyria discovered them during his conquest of the kingdom in 714 B.C. which, admired and imitated them [3], [4].

After renovation of Qanat in Iran and complication of their technologies, it was exported to the other regions in relation to various reasons. Dominance of Iranian kingdoms including "Hakhamaneshian, medes, Part-ha and Sasanian Empire" in 800 B.C to other countries, immigration of Iranian people to other regions and family relationships between Iranian with non-Iranian people can address some of these reasons.

Studying technical and hydraulic structures of qanats is like urban facilities and infrastructure besides taking into account the environmental, ecological, and social aspects of these structures; are among the most important topics in the recent decade. Considering that Iran has been the first place to adopt the qanats in 3000 years ago, studying their roles and values in urbanism system of Iranian cities, is of great importance. Concept of qanat is almost a familiar one in the Iranian's perception, especially in deserts regions; Because of approximately up to 50 years ago, qanat was the main water resource of many Iranian cities. In addition, Qanats have also had a significant role in formation of cities such as Yazd, Kazeroon, Esfadan, Tabriz, Shiraz, Ghazvin, Zanjan, and Kashan. As a result, these regions have developed quite a distinct culture and civilization which can be called the Qanat civilization sharing a unique cultural, socio-economic, architectural and political characteristic that would distinguish this region from others. It can be said that, the lessons of living with desert came from there [5].

Most of the researches in this area is about this role in forming the city structure and has focused the engineering aspects of their plan, planning \& structure. There is a small awareness to the role of the qanat, as the central element of city building, in the minds of residents and people regarding the effective aspects of qanats in their lifestyle and everyday lives especially with emphasis on public space \& urban landscape. in the current situation, there is a destructive \& non-environmental view among some people regarding this phenomenon [6]. This article is paying attention to the exploring perceptions and thoughts of people regarding the effects of qanats in their lifestyle and its relative values; by using case study about these roles in some cities.

Hence, the most important purpose of this study is to identify the values and functional aspects around the qanats in image that citizens have now, aiming to find a holistic image in regenerating qanat's socio-environmental phenomenon. The remainder of this article is structured as follows: first, the impact of qanat as a water supply infrastructure in urban landscape is investigated. Second, the role of qanat in forming the urban structure and morphology is monitored. The following section provides research methodology for gaining data based on everyday life qualitative technique. Finally, the main multi-dimensional roles of qanats in Iranian everyday life are shown.
Manuscript received June 15, 2017. This work was supported in part by the Shahid Rjaee Teacher Training University, Department of Architecture under Grant 234523.

The author is with Shahid Rjaee Teacher Training University, Tehran, Iran (e-mail: s.razzaghi@srttu.edu).

\section{MATERAIL AND METHODS}

\section{A. Qanat Infrastructure as Urban Landscape}

Landscape urbanism as a modern approach in urbanism 
and architecture; is focusing on the role of urban infrastructures as the most important public generative landscapes. According to this approach, urban infrastructures as crystallized in water supply system of qanat in the past; are major elements of urban form which shaping considerable and special visual, social and aesthetic effects on urban form. What most approaches and their publications have argued so far, was the way to standardize the technical aspect of the infrastructure systems in order to find an optimized structure for water supply their aspects of them. Instead, aesthetic, ecologic and social implications have had little attention so far [7].

At the beginning, the main concern of making qanat was access to the underground water by an innovative form (technique). But, later on, considering the environmental, social and physical aspects of this innovative structure in city assembles, have become one of the main factors of shaping Iranian cities morphology [2]. It seems that consideration to the position of urban infrastructures as natural and ecological factor on built environment can be taken into account more than as it is as functional factor. Thus, the main role of the designers (urban designers, architects, and landscape architects) is now to create meaningful forms of the landscape to improve the position and the effects of infrastructures and showing the applications of their natural capability in the urban form [8].

\section{B. Qanat Impacts on Urban Form and Environment}

The large numbers of Iranian cities have qanats as an internal part of their built environment. The organic form of that network and neighborhood centers of the cities like Yazd \& Mehriz has integrated with and defined by the formation of qanats' general network [9] (Fig. 1).

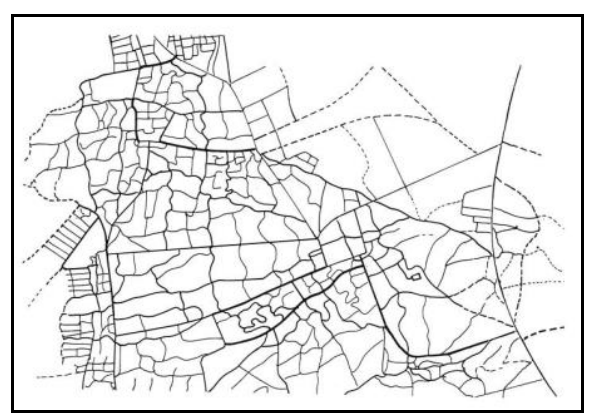

Fig. 1. The formation of street network based on Qanat steam network, the city of Mehriz, Yazd Province, Iran.

Most designers have not considered the infrastructures as influential elements on urban form either in whole or in district level [8]. But, about thousand years ago, according to mughannis own intuition and visions, applied the configuration of qanat in formation of galleries; outlet \& following streams have been the basis for shaping urban open spaces, configurations in various aspects.

\section{Qanat Forming Public Buildings}

Some of the qanats in Iran of which most evident is 40 kilometre Mehriz-Yazd qanat, not only join two cities together but also attach the main parts of the outstanding buildings to each other. For instance, the Mehriz-Yazd qanat first shapes the most beautiful elements of the Iranian residential architecture in inner city of Mehriz, and then it vitalize to Dolat-abad garden in the old city of Yazd [9]. In addition, to constructing qanats by ancient Iranians in order to prepare potable water in dry seasons, other facilities have been thought of such as water storages called ab-anbars, dykes and refrigerators known as Yakhchals. Meanwhile, ab-anbars as an effective public building in urban structure is used for saving water in rainy seasons and consuming it in rest of the year [10]. Domes and the upper badgirs (wind catchers) are the symbols of ab-anbars in building forms, from the viewpoint of visual landscape. These elements have the main role in legibility of the urban landscape. They are considered as a result of conformity between the image and the visual landscape. Ab-anbars in Naragh city are one of the architectural masterpieces from Qajar era which are working at the moment and people take advantage of their cold waters in summer (Fig. 2).

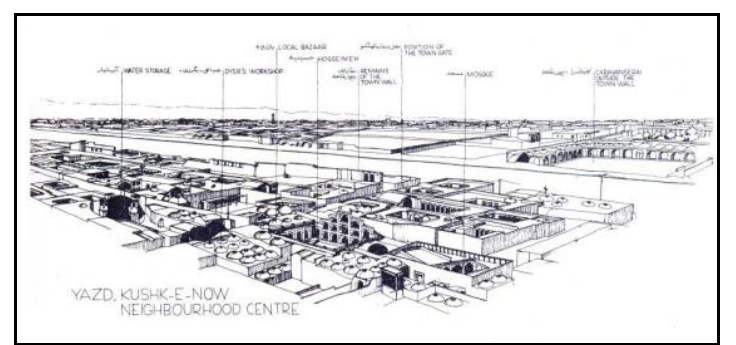

Fig. 2. Resting location of ab-anbars close to other architectural elements of the ancient neighbourhood centres, the city of Yazd, Iran.

\section{Qanat Forming Urban Environments}

In some Iranian cities, such as Mehriz, qanats outlet becomes the basis of urban open spaces in neighbourhood scale. In architecture scale, qanats become important elements in interior design of vernacular and historic buildings and landscaping. Thus, qanats are as a one of the most important structures in efficiency, prominence and flourish of Iranian vernacular architecture and urbanism [9]. Downstream of the outlet, the water runs through surface canals called 'jubs' (jūbs) which run downhill, with lateral branches to carry water to the neighbourhood, gardens and fields. The streets normally parallel the water streams called jubs and their lateral branches. As a result, cities and towns are oriented consistent compatible with the gradient of the land; what is sometimes viewed as chaotic to the western eye is a practical response to efficient water distribution over varying terrain [11]. Vail-e-Asr Street in Tehran is a good example of this phenomenon. Even now, qanat of this street until irrigate trees and greening the streetscape as well (Fig. 3).

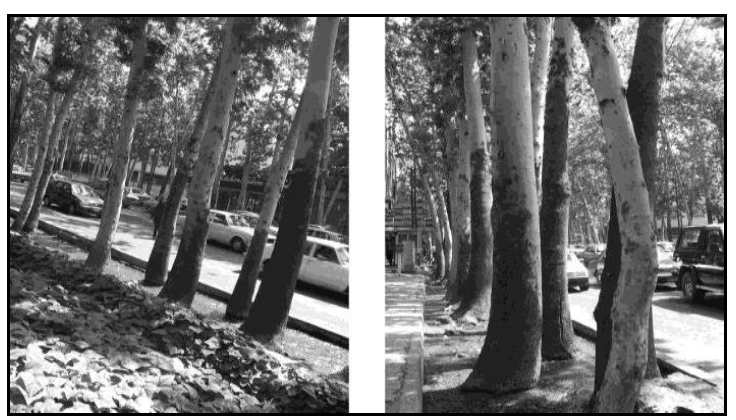

Fig. 3. The direction of bagh-e-ferdos qanat in Valiasr street main street, Tehran, Iran. 


\section{CASE STUdy AND INTERVIEWING IMPLICATIONS}

Everyday life as a participatory action research method is not isolated; rather, it is embedded in people and situations. Researchers often negotiate during research that is collected traditionally through means of data collection and creative and introspective research that relies on the positionality, perspective, and viewpoint of participants. Everyday life research focuses on the details and seemingly insignificant occurrences that collectively contribute to how a situation, phenomenon, or occurrence such as Qanats is interpreted and experienced by people. Such research seeks to understand social experience based on how people do and experience social life, which privileges experience as knowledge. The perspective becomes a study of social interaction in a natural environment that acknowledges extraordinary happenings while legitimating the ordinary events of life [12].

The basic data in this method is collected through interviews, participant observation, introspective journal writings, and other qualitative techniques. This approach is useful in analyzing qualitative data because it requires researcher to consider and negotiate ubiquitous themes that occur in everyday life, from work to play. Thus, two qualitative techniques were used: case study and structure interview.

A sample of $216(n=56$, Tehran; $n=96$, Yazd and $n=64$, Kashan) persons was selected for the research work using the stratified random sampling technique in winter 2009. Elderly people above 55 years old are questioned about the values of qanats in the past. Since most of the qanats exist in Yazd city (Semsare-Yazdi, 2000), 44\% of the people in this research are from Yazd (Table I).

\begin{tabular}{|c|c|}
\hline City & aged $>=55(\%)$ \\
\hline Kashan & 64 \\
\hline Tehran & 56 \\
\hline Yazd & 96 \\
\hline
\end{tabular}

TABLE II: DISCUSSION GUIDE QUESTIONS

Questions
People (aged>=55)
What was the most important application of the qanat in house
courtyard?
What were the most important application \& implications of the qanat
in the past in the neighborhood centre and alleys and streets?
Do you think qanats must be regenerated and new ones being
constructed across the city and neighborhoods?
In the current situation what is the most important role that can be
imagined for qanats in the alleys and streets?

Resident's perception can give a distinctive insight to design criteria of qanat which originally routed in their day to day life experience relating the form $\&$ structure of qanat itself and in city texture. The term 'perception' is used here in the general sense of how things are 'seen' [13]. It reflects motives, preferences and attitude to space. These people and cases were identified through reports and the observation technique within the condition that they be highly knowledgeable of the objective and diverse contexts of the study. Tehran, Kashan, Yazd, Naragh, Mehriz and Kish island are the most important cases of iran which have been invistigated in this research for exploring values are critical to be mentioned.

A semi-structured discussion guide was developed and pilot tested. It explored functions, insights and values about qanat roles, opinions and suggestions on qanat regeneration. Table II presents the questions contained in the discussion guide (Table II).

\section{RESULTS AND DISCUSSION}

Three perspectives have emerged from the analysis and interpretation of the data obtained: First, the qanat usage and values in micro scale as house courtyard. Second, roles and values of qanat in the public open spaces scale known as streets and neighborhood centre. Third, considering the Regeneration of qanats in cities from elderly viewpoint.

\section{A. The Position of Qanat in House Courtyard Scale}

Respondents Over 55 years old knew more functions for qanats, as have spent their childhood with qanat. In their responses, functions such as washing, irrigation, watering, aesthetical, security, rest, keeping historical and monumental aspects, and water economy; were among the most important roles of qanats in courtyards. In addition, having both qanat and Badgir in traditional Iranian houses for cooling purposes in the summer is another role in such places.

Results show that about $94 \%$ of respondents point out the washing, irrigating and watering purposes as most important roles of qanats in the past and present. With a slight difference $(92 \%)$ aesthetical function was seen as a next important role of qanats in house courtyards (Table III).

TABLE III: OPERATION OF EXISTING QANATS IN IRANIAN HOUSES

\begin{tabular}{lc}
\hline Usage for qanat & $\begin{array}{c}\text { persons (aged }>=55) \\
(n=216)(\%)\end{array}$ \\
\hline Washing, irrigation and watering & 94 \\
Beautifying house & 92 \\
negotiation and relaxing & 82 \\
Weather coolness & 78 \\
Security & 58 \\
comfort & 46 \\
Keeping historical and metaphorical & 32 \\
aspects & 21 \\
Water economy & \\
\hline
\end{tabular}

\section{B. The Position of Qanat in Street and Neighborhood Scale}

Responders have emphasized on the factors including environmental beautification, irrigation of trees, weather coolness, neighborhood activity nodes, comfort and symbolic\& historic aspects in qanat neighborhoods. Table 4 indicates the usages and frequencies of interviewees. Most of the interviewees considered to the irrigation (89\%) and beautification $(86 \%)$ roles of qanat in neighborhood centers. People above 55 and older, because of dealing with different aspects of qanats in neighborhood centers and urban alleys and streets; have directly referred to its historic, symbolic and cultural aspects in urban landscape $(81 \%)$. In fact if we return to the definition of cultural landscape by UNESCO (1992) which is "the combination of human and nature works", we arrive at a unique sample of qanat which includes historic, cultural and natural aspects (Table IV). 
TABLE IV: OPERATION OF EXISTING QANATS IN IRANIAN URBAN NEIGHBORHOODS

\begin{tabular}{lc}
\hline Usage for qanat & $\begin{array}{c}\text { persons (aged }>=55) \\
(n=216)(\%)\end{array}$ \\
\hline Irrigation of trees & 89 \\
Environment beautification & 86 \\
Protection of the historic & 81 \\
\&symbolic aspects Weather & 78 \\
coolness & 64 \\
Neighbourhood act. nodes & 48 \\
comfort & \\
\hline
\end{tabular}

\section{Regeneration of Qanats in Cities}

Even though qanats may not feature strongly in the usage arena, there appears to be a general sense of support for qanats provision. When asked, "Do you think we should provide more qanats in city?" about $75 \%$ of the respondents voted for more qanats provision. It is possible that some respondents may have been inclined to indicate 'yes' as they were not asked to bear the provision costs. Respondents were asked to share their personal thoughts in a follow-up open-ended question of why they support or do not support more qanats provision in cities (Kashan, Yazd \& Tehran). The replies were content analyzed, similar thoughts and words were coded and grouped under same representative themes and then independently verified to unpack the focus of individual attention. As summarized in Table V, the main reasons point to considerations of aesthetics (93\%) to beautify the environment \& functional (91\%) including personal usage for irrigation and washing purposes.

In some specific situations, a 62 years old man makes clear that pumps and modern pipes could not replace the old qanats. He says: "qanats used to provide the water of the neighbourhood for different purposes. And in addition, they were an aesthetic factor for the houses and the neighbourhood." 82 years elderly man says: "from what I have lived in traditional yazd houses, qanats can have a special role in the aesthetic point of view of the landscape and irrigation - and that's because of their special natural and environmental characteristics."

In addition to these, some people, argued the historicalmetaphorical (78\%), and tourism points (43\%). The existence of qanats in most parts of the historic quarters of Yazd is widely one of the main potentials for attracting tourists (Table V).

TABLE V: REASON FOR MORE QANAT PROVISION

\begin{tabular}{lc}
\multicolumn{2}{c}{ TABLE V: REASON FOR MORE QANAT PROVISION } \\
\hline Reason for more qanat provision & $\begin{array}{c}\text { persons }(\text { age }>=55) \\
(\mathrm{n}=216)(\%)\end{array}$ \\
\hline aesthetic & 93 \\
functional & 91 \\
environmental & 53 \\
socio-cultural & 62 \\
historic- monumental & 78 \\
tourism - heritage & 43 \\
\hline
\end{tabular}

\section{CONCLUSION}

As UNESCO has announced, $60 \%$ of the qanats across the world are located in Iran. But, in very few cities the subject of qanats and their mutual effects has been considered seriously. In fact, qanat for its visual aspects in the city - no matter it is still in use or not - must be considered in city development plans as a major element of the city infrastructures and utilities.

As the most respondents to the study \& also current formal urban development process in Iran shows the capability of qanat and its design configuration have been mainly neglected. The most respondent emphasized on the necessity of making reconstruction plan for qanats respecting their original design themes. It has been stressed that although the traditional function of qanat cannot be completely resumed, but it can be reorganized through specific role mainly in relation to urban landscape \& reinforcement of urban open space. The reconstruction of the underground city of Kish in Iran based on qanat is a good example in this mater [14], [15].

Concluding the results in the case studies and structured interviews with some of the elderly citizens old ( +55 yrs old) in the cities of Kashan, Tehran and Yazd; shows: there can be eight roles for qanats in the Iranian everyday life. The first is Functional Role: Qanats from the long past have been the main providers of water for agricultural purposes. Although At the present time, the qanats have been replaced by the modern deep wells, the agricultural lands of many Iranian cities in the central part of Iran such as Yazd, Kerman, Naein, Kashan, Shiraz, and Isfahan are still benefited from the qanats. In some cases, people also used to take advantages of the water of qanats for their personal use such as drinking, washing and irrigating their small gardens [16].

The second aspect is Socio-cultural role. qanats as the centres for socio-cultural activities and can be effective in definition of the neighborhood activity nodes. The Third role is Ecological. The design \& construction paradigm of qanat integrated with ecological process of each geographic region. The climatic \& geological structure of geographic locales in an environmental friendly approach was the essence of qanat construction \& operation system. Qanat as a watering system is operating based on its capacity to irrigate a specific geographical locale. A society created based on the qanat, understand the value of its each drop of water. Hence, waste of water reaches its minimum stage. Preventing the damage to the underground water supplies by qanats, because of its slow use of water resources; comparing to the damage caused by pumping water; is the most important value of the qanat from the ecological point of view. In other words, qanat is the metaphor of sustainable development [17].

The Fourth aspect is Economic role. Value of qanat and making the underground water flow without gravity, with no need to use any mechanical force and energy with considering all other environmental issues and other costs; is also very important from the economical point of view. It seems that qanats are still effective in economic improvement, using farmlands and a sustainable development. So removing qanats would be an irreversible mistake in economic terms [14].

The fifth aspect is visual role. Effect of visually aesthetic and improving visual quality of the landscape is obvious for everyone. Qanat path chains with its presence in the floors cape, is playing river role that beautifies the public view as well as supplying water for trees and plants. Attributes such as reflection, pleasant and vitality, from the presence of water in the urban landscape would be seen in qanats. 
The sixth aspect is cooling role. Qanats can be used for cooling as well as water supply [18]. Traditionally In wealthy homes, special rooms are constructed beside the underground stream with tall shafts reaching upward to wind catchers (badgir) above roof level. Air caught by the badgirs, which are oriented to prevailing summer winds, is forced down the shaft, circulates at water level, and provides a cool refuge from the afternoon heat of summer. Needless to say, land located above submerged qanat tunnels, and houses with private payabs, are highly valued [19].

The seventh aspect is psychological role. In eastern culture, water with its clearness characteristic - which means having visual clarity and cleaning power - is always one of the most important quadratic elements and a metaphor of clearness and transparency. This attribute that applies to the spiritual dimension of the human beings in its living environment, has a specific role in homes and public places. On the other hand, clearness with the water is the first condition for praying the creator of the universe.

The eight $\&$ final aspect is tourism and heritage role. as qanats are artifacts relating to old ages of life, has a historical and nostalgic figure with the Iranians. In views collected in this study, some respondents admitted this fact. But what is important for the time being is the saving and improving these aspects for the next generations and foreign visitors. For that, with the experiences like the underground city of Kish, we can bear tourism and heritage role for these cultural landscapes. With such view, qanats are part of country's cultural urban landscapes and serious attention needs to be paid from people and officials to save them.

\section{REFERENCES}

[1] D. Lightfoot, "The origin and diffusion of Qanats in Arabia: New evidence from the Northern and Southern Peninsula," The Geographical Journal, vol. 166, no. 3, pp. 215-226, 2000.

[2] M. Haeri, Qanat in Iran, Tehran: Cultural Research Bbureau, 2008.

[3] H. Gobolt, Les qanats: Une technique d'acquisition de l'eau, Mouton, 1979.
[4] M. Khansari et al., The Persian Garden: Ecohoes of Paradise, Mage Publishers, pp. 22-27, 2003.

[5] P. Beaumont, "Qanat systems in Iran," Bulletin of the International Association of Scientific Hydrology, vol. 16, pp. 39-50, 1971.

[6] A. Maleki and A. Khorsandi, "Qanat in Iran: The case study of Tehran qanats," Tehran: Urban Planning and Processing Co, 2006.

[7] E. Mossop, "Landscape of Infrastructure," The Landscape Urbanism Reader, New York: Princeton Architectural Press, 2006.

[8] G. Strang, "Infrastructure as landscape," Theory in Landscape Achitecture, Philadelphia: University of Pennsylvania Press, 2002.

[9] M. Behzadfar, Urban Infrastructures, Tehran: Shahidi Publisher, 2009.

[10] V. Ghobadian, "Climatic analysis of Iranian traditional buildings," University of Tehran Press, Tehran, Philosophical Society, vol. 112, pp. 170-181, 2004.

[11] M. Kheirabadi, Iranian Cities: Formation and Development, Austin: University of Texas Press, 1991.

[12] M. R. Boylorn, "Everyday life," The SAGE Encyclopedia of Qualitative Research Methods, California: SAGE Publications, Inc, 2008.

[13] A. Rapoport, Human Aspects of Urban Form, Oxford: Pergamon Press, 1977.

[14] S. Nan, "Investigation of qanats functions and roles in last and now," in Proc. 3th Cnogress of Iranian Architecture and Urbanism History, Arge-Bam, Kerman, pp. 114-127, 2007.

[15] H. Ahmadi et al., "The qanat: A living history in Iran," Water and Sustainability in Arid Regions, Netherlands: Springer, 2010.

[16] R. Abouei, "Conservation of badgirs and qanats in Yazd," Central Iran, in Proc. the 23th Conference on Passive and Low Energy Architecture, Geneva, Switzerland, pp. 38-47, 2006.

[17] A. Semsare-Yazdi, "An analysis of yazd qanats," in Proc. 2th Congree of Qanat, Regional Water Co. Yazd, pp. 65-75, 2000.

[18] Centre for Sustainable Development (Cenesta), Qanat Irrigation Systems: An Ancient Water Distribution System Allowing Specialised and Diverse Cropping in Desert Regions of Iran, Tehran, 2003.

[19] M. Honari, "Qanats and human settlement in Iran," 1989.

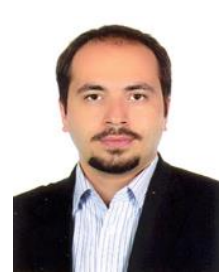

Sina Razzaghi Asl is an assistant professor in urban design at Shahid Rajaee Teacher University in Teharan, Iran. He holds the PhD in architecture in 2012 from Iran University of Science and Technology. Dr razzaghi's interests are landscape urbanism, ecological urban design, place making, urban open spaces. His current research interest is in two area: first, landscape-based climate change adaptation and second social network analysis and place making. The title of his book is "the Nature and Border of Urban Design" published in 2014. 